\title{
The Impact of Capital Adequacy Ratio (CAR) on Islamic Banks' Performance in Selected MENA Countries
}

\author{
ADEL Z. A. ALNAJJAR* \\ IIUM Institute of Islamic Banking and Finance \\ International Islamic University Malaysia, Kuala Lumpur, Malaysia \\ E-mail : aza201463@gmail.com, \\ ORCID: 0000-0002-6190-7816 \\ *Corresponding author
}

\author{
Anwar Hasan Abdullah Othman \\ Assistant Professor, IIUM Institute of Islamic Banking and Finance \\ International Islamic University Malaysia, Kuala Lumpur, Malaysia \\ E-mail : anwarhasan@iium.edu.my \\ ORCID: 0000-0001-5759-8216
}

Received April, 2021; Accepted May, 2021

\begin{abstract}
A strong capital adequacy ratio is crucial to a financial institution's success and helps it to survive any potential financial crisis. From Q1 2017 to Q4 2019, the influence of the Capital Adequacy Ratio (CAR) on the performance of Commercial Islamic Banks in MENA nations (Qatar, Oman, Bahrain, Kuwait, United Arab Emirates, Saudi Arabia, and Jordan) is examined. The performance measures utilized in this study are Return on Assets (ROA) and Return on Equity (ROE). The study's sample frame comprises all Islamic commercial banks in the designated MENA nations, with a sample size of 18 Islamic commercial banks. Panel data, fixed and random models, are applied in this study since there are multiple entities and time series. The findings of the study showed that the selected Islamic banks are committed to Capital Adequacy Ratio (CAR) which is defined under Basel III. This is considered the largest percentage regulated by the Basel Committee. The study also found that there is a statistically negative significant influence of CAR on both performance indicators ROE and ROA in the commercial Islamic banks in the selected MENA countries. The results of the study can be useful to a policymaker or decision-makers in the Islamic Banks industry. First, the research could be a reference to financial regulators such as central banks which may use the findings to provide regulation on optimal capital levels for local banks in terms of regulations, deregulations, and financial disruption. Next, the practice implications in the Islamic banking sector will provide them with insight as to how a bank's capital influences its earnings. Hence, management can work towards attaining an optimal structure that maximizes their performance as well as identifying "best" and "worst" practices associated with capitalization levels.
\end{abstract}

Keywords: Capital Adequacy, Performance, Islamic Banks, Return on Assets, Basel Committee, Financial Crisis.

Type: Research paper

This work is licensed under a Creative Commons Attribution 4.0 International License.

DOI: 10.51325/ijbeg.v4i2.70

\section{Introduction}

Commercial banks are one of the biggest and oldest cash-mediating financial institutions, with the primary goal of receiving deferred and current deposits from individuals and companies and reusing them to provide loans to individuals and non-bank economic units. As a result, banks play the part of economic units with income over and 
above their expenditures, as well as providing banking services. They also take on the role of funding economic units for individuals and businesses whose expenses exceed their revenue by lending processes. They also participate in acquisition processes, assist in the creation of businesses, and arbitrate in the marketing of financial stocks, as well as the purchasing and distribution of tradeable international coins and other bank coins (AlAli, 2019). The first international conference on Islamic Economics was conducted in Mecca by King Abdul Aziz University in 1970, which led to the establishment of Islamic Banks. Then, as the very first Islamic Commercial Bank in the United Arab Emirates (UAE), Dubai Islamic Bank (DIB) was established, followed by the Islamic Development Bank (IDB) in Jeddah, Saudi Arabia. Subsequently, other Islamic countries commenced their public or government banks and began to operate in Egypt, Sudan, Kuwait, Bahrain, etc. (Chachi, 2006; Shahar et al., 2017). The Islamic countries have therefore been influenced for a long time by the growth of these commercial Islamic Financial Institutions (IFIs).

However, capital adequacy represents the ability and effectiveness of banks to assess, guide and manage the risks they face with a view to scaling, managing and decision-making in line with strategy and policy in addition to improving their attitude toward competitiveness. Capital sufficiency aids in the pricing of financial services and the maximization of profits from banking activities. It is also helpful to the implementation of policies and procedures that are needed to mitigate various forms of risks. These dangers occur as a result of technical and electronic advancements, as well as the growing complexity of banking and rivalry between banks. As a result, banks must establish adequate capital to cover any potential crises and design the appropriate plan to secure the bank's existence at a greater percentage than the stipulated percentage. Also called as "Corrective Actions," supplying adequate capital to avoid monetary authority involvement in order to prevent its collapse (Almazari, 2017).

Capital is one of the main determinants of a bank's profitability (Hoffmann, 2011). Bank capital is important for individual banks' stability and soundness, as well as for potential growth and public interest in banks. It offers the opportunity to satisfy customers and protect the bank from unforeseen losses under the banks' legal lending limits. Bank capital is also a key prudential regulation problem. Therefore, sufficient capital is considered to be a sine qua non in the financial sector and, in particular, for banks. In the books of banks and investment firms, capital adequacy requires the setting of minimum standards for market risk. This involves identifying norms and covering criteria for risk management and solvency ratio (AlAli, 2019; Lenee \& Sulaiman, 2016).

Banks as commercial entities are expected to make profit in order to absorb losses from their normal earnings. Financial performance is an estimation of a bank's financial position or profitability in order to provide useful insight into the bank's health and soundness using an index that applies to two pieces of financial data by dividing one quantity by the other (called as financial ratios). Some literature have attempted to show that capital adequacy measures do indeed influence the financial performance variables of companies in general and of banks in particular (Lenee \& Sulaiman, 2016). The ratio of net profit after taxes to total assets is known as Return on Assets (ROA). This ratio, which measures the company's operating efficiency, is calculated using the profit received by the corporation from its net assets. Return on Equity (ROE) is a financial efficiency metric that is calculated by dividing net profit after taxation by the shareholders' gross equity. The rate of return on a company's investment for its shareholders is calculated using this ratio (Abdel \& Kabajeh, 2012). Earnings Per Share (EPS) is the most recent financial result of this report. This is the fraction of a firm 's earnings that is allocated to 
each share of common stock, after taxes and preferential dividends. To calculate EPS, divide the net profits earned during the reporting period (typically quarterly or yearly) by the number of shares outstanding during the same time. Because the number of outstanding shares will change, the weighted average is frequently utilized (Islam, Rashidul, 2015). In order to face ordinary and surprising withdrawals movements and have financial coverage, the banks must maintain a certain rate of capital appropriateness. Particularly, following the financial crisis 2008, Basel III Accords have identified the ration of capital adequacy that the bank must maintain is $10.5 \%$. Interestingly, central banks of the Middle East countries (ME) have also identified a ratio over. That has been adopted by the Basel Committee to be adopted by the banks in those countries.

Based on the aforementioned regarding the importance of capital adequacy, the objective of this study is to identify the extent to which Islamic banks in the selected MENA countries comply with the capital adequacy standard under Basel III agreement. In addition to recognizing the effect of capital adequacy on the performance Return on Assets (ROA), and Return on Equity (ROE) in the designated MENA countries.

This study is organized into four parts. The first part introduces the background of the study, problem statement, research objectives, this part also explains and discusses some main concepts of the study such Islamic banks, Basel III accords with highlighting the capital adequacy ratio and performance. It is followed by part two which discusses the previous literature regarding impacts of Capital Adequacy Ratio (CAR) on the performance in banking sector and particularly the Islamic banks, and the theoretical framework of the study. Part three includes research methodology of the study including population, target samples, data collection and analysis as well as methods (approaches) used in the study. Finally, part four explain the findings in addition to providing some recommendations for further studies.

\section{Islamic Banks}

The peculiarity of Islamic banks arises from the fact that they are subject not just to the scrutiny of financial regulatory organizations that structure the banking industry (e.g., central banks). But are also subject to Shari'ah law guidelines controlling their financial dealings and contracts. These characteristics will have an impact in comparison to their conventional counterparts on Islamic banks' capital structure decision. The following criteria, according to a research done in 2020 by (Al-Hunnayan, 2020), can influence capital structure in Islamic banks in the chosen MENA nations. Namely, size of the company, tangibility of the business's assets, growth opportunity, liquidity of the business's assets, bank profitability, and financial market development are all factors to consider. According to the findings of (Al-Hunnayan, 2020), size and growth have a beneficial impact on the capital structure of Islamic banks in the MENA nations studied. Profitability and financial market expansion, on the other hand, have a negative impact on capital structure of Islamic banks in selected MENA countries. In Jordan, (Almanaseer, 2019) conducted a study on 13 Jordanian commercial banks listed on the Amman Stock Exchange to investigate in the determinants of capital structure in Jordanian banks. (Almanaseer, 2019) found that there is a negative relationship between capital structure with profitability, liquidity, and tangibility. In contrast, he concluded that capital structure is significantly positively influenced by age, growth, risk, size, and tax. However, the financial crisis in 2007-2008 showed that the banking system did not enjoy a heath and sound capital to cover potential crisis. Additionally, sudden huge number of withdrawals in a short period led many banks to bankrupt worldwide. Therefore, Basel III came to reform the regulations through imposing a higher capital adequacy to enhance a bank's 
ability to deal with losses, bear risks (e.g. Bankrupt, massive number of withdrawals), and run stable operations in future. In addition, Basel III attempted to improve financial sector stability by requiring banks to maintain higher capital ratios. Reserves and unutilized capital amounts, on the other hand, may have an impact on bank profitability. The study's goal is to assess how closely Islamic banks in the specified MENA nations conform to the Basel III international agreement's Capital Adequacy Ratio (CAR). And how much they understand the impact of increasing the Capital Adequacy Ratio from 8\% to 10.5 percent on financial performance measures such as Return on Assets (ROA) and Return on Equity (ROE).

Following the 2007-2008 global financial tsunami, Basel III was suggested in 2010 by the Bank for International Settlements (BIS) in a response to this financial tsunami. BIS determined that banks must maintain a higher minimum capital ratio with a target of $10.5 \%$ by 2019 . Higher BIS ratios indicate a greater potential for risk absorption in the eyes of the banking supervisory authority. Thus, banks can engage in more diverse risky activities approved by the banking supervisory authority, resulting in higher operating income from those authorized activities (Li et al., 2016). Furthermore, insolvency risk is determined by the portfolio's level of risk as well as the number of financial resources available to absorb losses. The risk premium charged for uninsured loans and the strength of risk management practices have an effect on a bank's net operating incomes. Furthermore, a bank's capital level has a significant impact on expenses by offering an alternative to deposits as a means of financing (Li et al., 2016). Banks with a higher capital ratio have lower costs (cash flow), making them less expensive or even efficient in comparison to banks with lower capital ratios. As a result, bankers prefer a lower capital adequacy threshold because deposit guarantee and a lender of last resort facility are provided by the regulatory body and central bank. Although supervisory authorities prefer a high capital ratio because it improves a bank's capacity to manage risks, settle losses, and maintain stable operations (Li et al., 2016).

\section{The Concept of Capital}

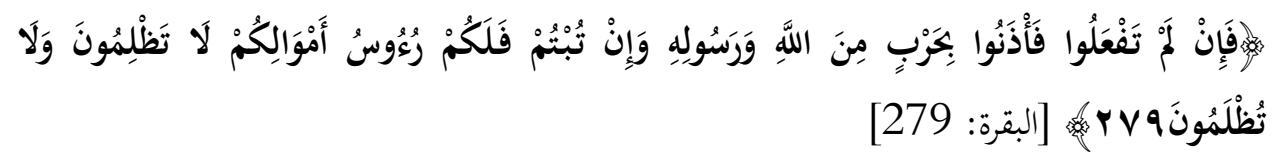

"for if you do it not, then know that you are at war with God and His Apostle. But if you repent, then you shall be entitled to [the return of] your principal: you will do no wrong, and neither will you be wronged" Baqarah $\{2: 279\}$.

The term ruūsu [رُؤوسنُ] comes from the root letters ra-hamza-seen and is used to describe a variety of things. "The head, a chief, or a command," for example. The term in the ayah, on the other hand, refers to the "capital or principal of money." This means that the initial capital will not be reduced. Instead, after repenting from trading in "riba," the creditor will get simply what he lent, with no increase or reduction. Therefore, the ayah informs us clearly the importance of preserving the capital in Islam, even in the case of dealing in a prohibited transaction (Riba, 2020).

The word "capital" is derived from the Latin word, "capitas" which means "main" or "principal," and it is among the most researched, but still one of the most sophisticated and baffling economic types." Nonetheless, The scientific 
community has been debating the definition of the term "capital" for decades, but scientists are still divided on the term's substance (Butkova, 2020). The capital of a bank can be defined as the value of its net assets. In terms of practice, the capital is the sum of the capital paid-up of the bank and its accumulated capital reserves. A bank's capital is critical to the security of its depositors and, as a result, to the preservation of public trust in its operations. Supporting its long-term stability and growth is equally critical (Molyneux, 2006).

During the classical period, the definition of capital shifted from pre-classical economists' 'fund' concept to a juxtaposition of the 'fund' concept with the phrase 'physical capital.' Then, when the nineteenth century arrived, technical advancements fueled rapid industrialization in Western European countries. The neoclassical 'marginal revolution' in economics was increasingly stressed by the incorporation of the idea of 'physical capital,' i.e. capital goods as means of production, and by the quantification and measurement of it. (Trivedi, 2013). As developed economies have become more important and more knowledge-based and services-based economies, the emphasis has been changed to the central role of 'human resources' instead of former labor in economic theories. Endogenous growth models consider investments in skills and education to be a kind of human capital or knowledge capital. Investments in intellectual property may also be viewed as a means of accumulating intellectual capital (Trivedi, 2013). From the 1990s onwards, the focus has moved toward "financial capital" and the "fund" idea of capital revives. It is an indisputable fact that the financial sector and the explosive accumulation of financial resources have had a rising impact over the last two decades. The accumulation of "financial capital" has advanced without hindrance and at unparalleled levels since the era of information and communication technology (Trivedi, 2013).

\section{Capital Adequacy Ratio (CAR)}

Banking capital is an important aspect of the balance sheet since it demonstrates how safe and sound the bank is 'solvent'. Unlike bank liquidity, which refers to a bank's capacity to meet its commitments on time. A bank's solvency refers to its capacity to repay its debts in the long run. When it comes to bank liquidity, there is a trade-off between protection and returns since the more money there is, the lower the ROE. This is because the capital resources of a bank are kept in the form of assets such as government securities that are very secure and thus low yielding (Molyneux, 2006). However, from the bank's perspective, capital is expensive since higher capital means low equity holders' returns. From a regulatory point of view, capital is a buffer required for covering future losses until it has to be paid on deposits. The amount of capital required by regulators is known as regulatory capital. Because local and international authorities are interested in guaranteeing a safe and healthy financial industry, the question of how much capital is sufficient has become a contentious issue (Molyneux, 2006).

\section{Capital Adequacy Ratio (CAR) Based on Basel III}

This ratio is known as Total Capital-to-Risk Weighted Assets Ratio. CAR is the overall capital indicator of a bank. This ratio establishes a bank's ability to fulfil temporary obligations and other risks such as market risk, operating risk, credit risk, and others. It also calculates the amount of capital used to promote the risk assets of the banks (AlHares \& Saleem, 2017). In addition to Tier 1 capital, the ratio measures Tier 2 capital, 
which is a type of supplementary bank capital. Undisclosed reserves, general loss reserves, subordinated debt, hybrid debt, and equity are all part of Tier 2 capital. The Tier 2 capital ratio reveals the amount of losses a bank can tolerate in the case of a winding-up, which means depositors are less protected (Al-Hares \& Saleem, 2017).

The countercyclical buffer's goal is to meet the broader macroprudential goal of shielding the banking system against cycles of excessive aggregate loan expansion. The minimum criteria for risk-weighted assets (RWAs) are 4.5 percent common equity/RWAs, 6.0 percent Tier 1 capital/RWAs, and 8.0 percent total capital/RWAs . The difference between the overall capital requirement of $8 \%$ and the Tier 1 requirement can be used to satisfy Tier 2 and higher categories of capital (Al-Hares \& Saleem, 2017). The following table shows Basel III capital standards to be met by January 2019:

Table 1. CAR Based on Basel III

\begin{tabular}{|l|c|c|c|}
\hline & $\begin{array}{c}\text { Common Equity } \\
\text { (After } \\
\text { Deductions) }\end{array}$ & $\begin{array}{c}\text { Tier 1 } \\
\text { Capital }\end{array}$ & Total Capital \\
\hline Minimum & $4.5 \%$ & $6.0 \%$ & $\% 8.0$ \\
\hline
\end{tabular}

\begin{tabular}{|ll|}
\hline Capital Conservation Buffer & $2.5 \%$ \\
\hline
\end{tabular}

\begin{tabular}{|l|l|l|l|}
\hline $\begin{array}{l}\text { Minimum Plus Capital Conservation } \\
\text { buffer }\end{array}$ & $7.0 \%$ & $8.5 \%$ & $10.5 \%$ \\
\hline Counter-Cyclical Buffer & $0-2.5 \%$ & & \\
\hline Maximum & & & $13.0 \%$ \\
\hline
\end{tabular}

Source: (Al-Hares \& Saleem, 2017)

BCBS increased the minimum needed CAR from $8 \%$ in Basel II to 10.5 percent in Basel III as a result of the financial crisis, as seen in the table above. Furthermore, it concentrated its reforms on capital quality, as it required a higher proportion of common equity in the bank's overall capital (Fatma, 2019).

\section{Performance}

The word "Performance" is derived from the old French word "Parfournir". The meaning of which is to carry it through, to carry it out, or to make it happen (Naz et al., 2016). The act of performing, executing, and attaining activities that must be judged against predetermined criteria of precision, money, fullness, and timeliness is referred to as performance. It is a phrase used in finance to describe the financial measurement of a company's policies, actions, and operating performance. It is used to assess the company's growth, compliance, and financial status. The firm's return on investment, assets, equity, capital employed, and profitability all represent these outcomes (Naz et al., 2016).

Financial performance is the extent to which the financial health of a company is measured over time. In other words, it is a financial action used for the control of existing and non-current properties, borrowing, equity, sales, and expenditures of a company for its shareholders. It aims primarily at providing shareholders and stakeholders with full knowledge to the point to enable them to take decisions. It can be used to analyze related businesses in the same sector or to compare the aggregate industries (Naz et al., 2016). Therefore, financial performance is evidently the ability of companies, including banks, 
to lower their costs and increase revenues so as to meet their obligations in relation to others. While simultaneously determining the extent of optimal use of resources. The performance of banking institutions is important because of their role as a financial intermediary, transferring funds from those with financial surpluses to those with financial deficits in the form of investments and credit financing. As well as the magnitude of the funds dealt with and the speed with which they are turned over. Measurement process must therefore be conducted continuously on the basis standards and foundations, which illustrate the financial performance of these institutions and the true results of them. The aims of these institutions are to achieve many objectives, including: the reputation, financial goals, effectiveness and effective use of means, and the development of decisionmaking. The objectives of this institution are to assist the institution to exploit all available resources to reach its financial aims (Deya'a, 2018).

\section{Literature Review}

In Bahrain, (Hawaldar et al., 2017) conducted a study on commercial banks (Islamic and Conventional Banks). The aim of this analysis is to examine the performance of Bahrain's commercial retail banks (both conventional and Islamic). For a 15-year cycle from 2001 to 2015, the ROA and ROE financial ratios were applied to metrics such as profitability, liquidity, operational efficiency, capital adequacy, and leverage. The author gathered secondary details from the published financial statements of the Kingdom of Bahrain's commercial and Islamic bank accounts over a 15-year period. The research relied on panel data to assess the actions of each bank's variables over time and space. The study covered seven commercial banks in which all these banks are listed on Bahrain Bourse. Out of these seven banks there are three Islamic banks and the other four banks are conventional. It was found that the profitability and capital adequacy of the banks are statistically correlated with a significant difference in capital adequacy between Islamic and conventional banks.

(Hafez \& El-Ansary, 2015) analyzed the elements that influence Egyptian commercial banks' capital adequacy. The yearly financial statements were used to get financial data from the Bank-Scope database. In Egypt, there are 40 commercial operational banks, although empirical investigation was done on 33 banks in the interim period between 2003 and 2013. According to the analysis, profitability has little impact on the capital adequacy ratio, with the exception of return on assets (ROA), which is highly linked to the capital adequacy ratio (CAR) positively.

(Tabash \& Hassan, 2017) evaluated Islamic and conventional banks' solvency, profitability, and liquidity in the United Arab Emirates (UAE). The study selected all fully-fledged sample of Islamic banks and 14 conventional banks operating in the UAE between 2011 and 2014. Balanced data for Islamic banks and conventional banks in the UAE was collected from various sources. The data analysis was performed using Microsoft Excel, EViews version 7, and SPSS version 22. In these years, the UAE Islamic and conventional banks' liquidity, profitability, and solvency ratios are measured and compared. The research found that for UAE commercial banks, profitability and capital adequacy ratios are fine. Further, the results of the stepwise regression analysis show that liquidity and capital adequacy are factors in the profitability of the UAE conventional banks.

(Polat \& Al-khalaf, 2014) used panel data and modelling techniques such as robust estimation, fixed effect, generalized least square (GLS), and feasible GLS. The study's 
aim is to provide analytical evidence to help explain some of the internal bank variables that influence the CAR for listed banks in Saudi Arabia (KSA). The data covered the financial years of Saudi Arabian banks listed on the Saudi Arabian Stock Exchange from 2008 to 2012. It was found that ROA has a positive significance on CAR.

In Jordan, (Tamimi \& Obeidat, 2013) analysed the financial accounts of Jordanian Commercial Banks registered on the Amman Stock Exchange from 2000 to 2008. To assess the variables of capital adequacy ratio in these banks, the study employed Multiple Linear Regression (MLR) Analysis and the Correlation Coefficient (Pearson Correlation). The study's findings reveal a favorable statistical association between capital adequacy ratio and return on assets (CAR and ROA). The link between capital adequacy and Return on Equity, on the other hand, is inverse.

(Alajmi \& Alqasem, 2015) had done a study aimed at identifying the impact of seven internal factors. From 2005 to 2013, these criteria were Loans to Deposits, Return on Assets (ROA), Non-Performing Loans to Total Loans, Dividend Payout, Total Liability to Total Assets, and Return on Equity (ROE) of five traditional Kuwaiti banks on capital adequacy ratio (CAR). The study's findings revealed that capital adequacy ratio (CAR) and return on assets (ROA), as well as size (total liabilities to total assets), had a substantial negative association. The findings of a fixed random model, on the other hand, demonstrated that DIVIEDEND, LAR, LDR, NPLLR, and ROE had no effect on capital adequacy ratio. Nonetheless, the results of the random effect model revealed an inverse association between the bank's SIZE (total liability to assets) and CAR. Similarly, ROA and capital adequacy ratio have a negative significant association. In contrast, the Loan to Deposit Ratio (LDR) has a positive impact on the capital adequacy ratio. Under the random effect model, however, loans to assets, dividend payout, non-performing return on equity (ROE), and Loans to Total Loans have no significant impact on CAR.

In a study was conducted in Egypt, (Youssef, 2016) examined the banking sector profitability to highlight the most crucial variables that have a direct effect on the performance of this vital sector. From 2004 to 2014, a quarterly data model was used in the research. The model employed Cointegration approach to evaluate the long-run connection between bank benefit and a variety of bank factors for the technique. Liquidity, capital adequacy, and the percentage of non-performing loans are examples of these factors. The primary findings of this study revealed that the banking sector's profitability was negatively related to capital adequacy, the proportion of provisions for loans, and the deposit-to-total-asset ratio. On the contrary, it is positively connected to the size of the banking industry, indicating that the banking industry benefits from economies of scale.

(Bilal \& Salim, 2016) gathered yearly data for all commercial banks in Oman from 2013 to 2015 in order to investigate the impact of Basel III implementation on the financial performance of Omani commercial banks. The authors employed a correlation analysis model and ordinary least square (OLS) estimate using an SPSS 17.0 package to assess the association between Basel III implementation and financial performance. Net-Interest Margin (NIM), return on equity (ROE), efficiency ratio (EFR), debt to equity ratio, and return on assets were the financial performance indicators in this study (ROA). The results of the research indicated that the Basel III implementation had a positive effect on the financial performance of the commercial banks in Oman. Nonetheless, this effect is not statistically significant.

In an empirical study was conducted in Syria, (Nahal, 2015) aimed at examining the determinants of the banks' industry profitability. The data collected were for 11 of 
commercial banks working in Syria during the period from 2007 to 2014. The study investigated the impact of loans, bank size, deposits, non-interest income as well as capital adequacy on the profitability which was measured by return on equity (ROE) and return on assets (ROA). The study utilized panel regression analysis and correlation. The findings of this study showed that total deposits to total assets negatively and significantly influence the profitability. In contrast, capital adequacy ratio (CAR) as well as size have a positive and significant influence on banks' profitability factors. Therefore, the study recommended that banks may improve their profitability by decreasing the ratio of total deposits to total assets, but they should increase their capital adequacy ratio (CAR).

In Palestine, (Abugamea, 2018) conducted a study that covered data for 20 years from 1995 to 2015 except Net-Interest Margin (NIM) started from 2001. All of the information was gathered from the Palestine Monetary Authority's (PMA) statistics (Publications). The figures for GDP per capita in constant prices (US dollars) and inflation in percentages are from the Economic and Social Monitor publications. The purpose of this study, on the other hand, was to look into the impact of bank-specific and macroeconomic factors on the efficiency of the Palestinian banking system. The impact of bank capital, loans, asset size, economic growth, deposits, and inflation on financial performance indicators is investigated using the Ordinary Least Square approach in this article. These factors are return on equity (ROE), Net interest margin (NIM) as well as return on assets (ROA). The main findings show that size positively had an influence on ROE. Similarly, Capital is positively related to ROA. In addition, loans had also a positive correlation with both ROA and ROE. On the other hand, deposits had a negative relationship with both ROE and ROA.

\section{Conceptual Framework}

This study's theoretical approach intends to investigate the impact of capital adequacy ratio (CAR) on Islamic banks performance in selected MENA nations. As a result, three factors are included: Capital Adequacy Ratio (CAR), Return on Assets (ROA), and Return on Equity (ROE). The capital adequacy ratio (CAR) is a variable that is independent. Return on Assets (ROA) and Return on Equity (ROE) are dependent variables, implying that the study has two models. Using basic regression analysis, the researcher determined the magnitude of the influence of independent variables on dependent variables.

Figure 3.1 The Theoretical or Conceptual Framework

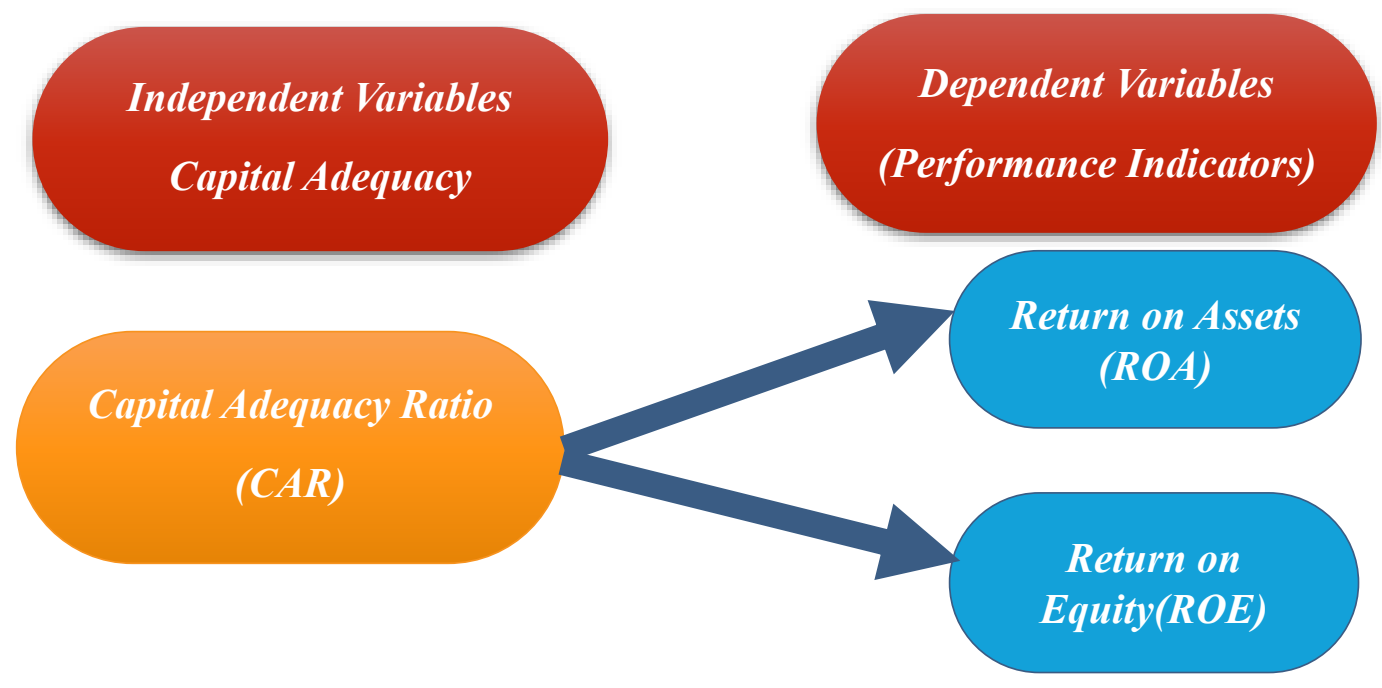




\section{Dependent Variables}

\section{Return on Assets (ROA)}

This indicator is determined by dividing net profit after taxes by total assets. This measurement of the company's operating efficiency is based on the profits generated by the company from its total assets. The ratio can be calculated by applying the following formula (Abdel \& Kabajeh, 2012): Net profit after taxes/Total assets.

\section{Return on Equity (ROE)}

This ratio is calculated by dividing net profit after tax by total shareholder equity. This ratio determines the rate of return on a company's investment for its shareholders. To calculate this indicator, the following formula is applied (Abdel \& Kabajeh, 2012): Net profit after taxes/Total shareholders' equity

\section{Independent Variable}

\section{Capital Adequacy Ratio (CAR)}

It is regarded as one of the most critical measures of the financial sector's financial solvency, as well as a safety valve to protect depositors and promote the banking system and financial institution stability and performance (Almazari, 2017). However, the formula is used to compute CAR as the following (Hafez \& El-Ansary, 2015):

$\mathbf{C A R}=\frac{\text { Core Capital (Tier } 1)+ \text { Supplemetary Capital (Tier 2) }}{\text { Risk }- \text { Weighted Assets }(\text { RWA })} \times 100$

Based on the literature and conceptual framework establishment, the research hypotheses can be as follow:

H1: Capital Adequacy Ratio (CAR) has significant influence on Return on Assets (ROA).

H2: Capital Adequacy Ratio (CAR) has significant influence on Return on Equity (ROE).

\section{Research Methodology}

\section{Population and Sample Size}

The population of this study covers Islamic banks in selected MEMA countries (Qatar, Oman, Kuwait, Bahrain, United Arab Emirates, Kingdom of Saudi, and Jordan). The entire number of Islamic banks in the selected countries is 36 . However, the researcher in this research collected quarterly data from 18 Islamic banks in the selected countries. And these 216 observations of data were found sufficient for doing this analysis.

Table 2. Summary of the sample size 


\begin{tabular}{|c|c|c|c|}
\hline Country & Bank & Country & Bank \\
\hline \multirow[t]{2}{*}{ Qatar } & \multirow{2}{*}{$\begin{array}{l}\text { Qatar Islamic Bank (QIB) } \\
\text { Qatar International Islamic } \\
\text { Bank (QIIB) } \\
\text { Masraf AlRayan }\end{array}$} & Kuwait & $\begin{array}{l}\text { Kuwait Finance House } \\
\text { (KFH) } \\
\text { Warba Islamic Bank }\end{array}$ \\
\hline & & \multirow{3}{*}{$\begin{array}{l}\text { United Arab } \\
\text { Emirates } \\
\text { (UAE) }\end{array}$} & Dubai Islamic Bank (DIB) \\
\hline Oman & $\begin{array}{l}\text { Nizwa Bank } \\
\text { Al-Izz Islamic Bank }\end{array}$ & & $\begin{array}{l}\text { AbuDabi Islamic Bank } \\
\text { (ADIB) } \\
\text { Mashreq Bank }\end{array}$ \\
\hline \multirow{3}{*}{ Bahrain } & \multirow{3}{*}{$\begin{array}{l}\text { al Baraka Islamic Bank } \\
\text { ABC Islamic Bank } \\
\text { Bahrain Islamic Bank } \\
\text { AlSalam Bank }\end{array}$} & & Sharjah Islamic Bank (SIB) \\
\hline & & $\begin{array}{c}\text { Saudi Arabia } \\
(\text { KSA })\end{array}$ & Bank Aljazira \\
\hline & & Jordan & $\begin{array}{l}\text { Jordan Islamic Bank (JIB) } \\
\text { Safwa Islamic Bank (SIB) }\end{array}$ \\
\hline
\end{tabular}

\section{Data Analysis}

As the research method used in this study is quantitative, statistical tools such as the Statistical Package (STATA) and Microsoft Excel are required to analyze the data collected. Thxis paragraph covers descriptive analysis of data.

\section{Descriptive Analysis}

Descriptive statistics are used to sum up data in an organized way by describing the link between the sample and the population variables (Yellapu, Vikas, 2010). However, the researcher utilized STATA software to analyze the descriptive statistics of the data collected.

\section{Simple Linear Regression}

A substantial linear correlation between the explanatory and independent variables is employed when one variable is used to describe another variable in terms of a linear relationship. Basic linear regression is the best model for evaluating the value of one variable in terms of another (George et al., 2020). The estimate of the coefficients b0 and b1 of a linear model that predicts the value of a single dependent variable $(\mathrm{y})$ in relation to a single independent variable (x) in the form is known as simple linear regression (George et al., 2020):

$$
y=\beta_{0}+\beta_{1} x_{1}+u
$$

Where:

Y represents a dependent variable $=$ Return on Assets $(\mathrm{ROA})$ or Return on Equity $(\mathrm{ROE})$.

$\beta 0=$ Intercept or constant.

X1= Capital Adequacy Ratio (CAR).

$u=$ Error

METHODOLOGY OF DATA ANALYSIS 
As the research includes two dependent variables and one independent variable, we have two models: ROA and ROE. However, the same steps of the analysis are conducted on both models. In this analysis, there are many classic assumption tests. The first step is to perform a normality test. This test determines whether the dependent and independent variables in a regression model have a normal distribution or not. A normal or near-normal distribution is a strong regression model. Next, the researcher tested the availability of panel data by conducting pooled OLS and then regression random effect model. And then Breusch-Pagan LM test is conducted to confirm the availability of panel data. The result of the latest test leads us to the next step. Since the panel data is existing, the random and fixed effect models tests have been conducted. To explain, the fixed and random effect models are used to determine the significance of the impact of the independent variable on the dependent variable. In the following step, the Hausman test is conducted to select between random or fixed which one is fit. The next test is to test the assumption of time series by performing the serial correlation test. Following this test, the Heteroscedasticity test is conducting to test the cross-sectional between units. These last two tests (Serial Correlation and Heteroscedasticity) are known as Diagnostic Tests. Finally, the robust test is conducted on the selected model "random" to autocorrect both models of the study ROA and ROE.

\section{Findings and Discussion}

\section{Descriptive Analysis}

Table 3. Descriptive Analysis 2021

\begin{tabular}{|c|c|c|c|}
\hline Variable & ROA & ROE & CAR \\
\hline Mean & 0.0095342 & 0.0795046 & 0.1927213 \\
\hline Std. Dev & 0.0098544 & 0.0683572 & 0.0394013 \\
\hline Min & -0.0519 & -0.1553 & 0.081 \\
\hline Max & 0.0566 & 0.2568 & 0.3539 \\
\hline Variance & 0.0000971 & 0.0046727 & 0.0015525 \\
\hline Skewness & 0.1020109 & 0.3551345 & 1.338535 \\
\hline Kurtosis & 12.57673 & 2.728546 & 5.97596 \\
\hline Observations & 216 & 216 & 216 \\
\hline
\end{tabular}

Source: (Prepared by the author, 2021)

This table contains the descriptive details about the data under investigation for use in regression. From Q1 2017 to Q4 2019, statistical data and details were taken from the records of 18 Islamic banks, according to this fact. As a result, each variable contains 216 observations. Minimum, maximum, mean, Standard Deviation, skewness, and kurtosis statistics are among the descriptive statistics that have been observed. Skewness, on the other hand, assesses the degree of asymmetry in the series. Because their skewness is positive, both the dependent variables return on assets (ROA) and return on equity (ROE) have a long right tail. Similarly, independent variable capital adequacy ratio (CAR) also has a positive skewness. Kurtosis measures peak and flatness of the distribution of the series. The table above clearly shows that ROA is a leptokurtic (peaked) since its kurtosis is higher than 3. While ROE OE is Mesokurtic since kurtosis is within 3 which means it is normally distributed. CAR is a leptokurtic (peaked) since its kurtosis is higher than 3. 


\section{Estimation Results}

\section{Results of Model ROA}

Summary of results of Model 1: ROA

Table 4. Results of Panel Data Analysis Dependent Variable: ROA

\begin{tabular}{|l|c|c|c|c|}
\hline \multicolumn{1}{|c|}{ Analysis } & Pooled OLS & $\begin{array}{c}\text { Random } \\
\text { Effect }\end{array}$ & $\begin{array}{c}\text { Fixed } \\
\text { Effect }\end{array}$ & $\begin{array}{c}\text { With } \\
\text { Robust }\end{array}$ \\
\hline Constant & 0.0176162 & 0.0153446 & 0.0146434 & 0.0176162 \\
\hline InVCAR & -0.0419364 & -0.0310492 & -0.026511 & -0.0419346 \\
\hline Breusch-Pagan LM & \multicolumn{2}{|c|}{ Prob>Chibr2=0.0000 } & - & 0.0000 \\
\hline Hausman test & - & \multicolumn{2}{|c|}{ Prob>Chi2=0.6789 } & 0.6789 \\
\hline Observations & 216 & 216 & 216 & 216 \\
\hline Serial Correlations & - & 0.0000 & - & 0.0000 \\
\hline Heteroskedasticity & - & 0.0000 & - & 0.0000 \\
\hline
\end{tabular}

Source: (Prepared by the author, 2021)

Through the previous table 5.2, we can obtain the equation of the model as the following:

$$
\mathrm{ROA}=0.0176162-0.0419364 \mathrm{CAR}
$$

\section{Analysis of the Model (1) ROA:}

\section{Panel Data Analysis}

The null hypothesis is rejected since the p-value is less than 0.05 , therefore the random effect model is more appropriate than OLS (pooled model). The second typical test in applied panel data analysis is to decide which model is better:

\section{Random or fixed effects Analysis.}

Hypothesis:

$\mathrm{H}_{0}: \operatorname{Cov}\left(\alpha_{\mathrm{I}}, \mathrm{x}_{\mathrm{it}}\right)=0$ (Random Effect)

$\mathrm{H}_{1}: \operatorname{Cov}\left(\left(\alpha_{\mathrm{I}}, \mathrm{x}_{\mathrm{it}}\right) \neq 0\right.$ (Fixed Effect)

When the null hypothesis (H0) is rejected, the fixed effect model is used. Otherwise, the random effect model will be more relevant in this case. The fixed effect model is used first, followed by the random effect model. And finally, the Hausman test will be applied to opt the appropriate model either the fixed or random. In the case of pvalue of the Hausman test is $<.05$, the fixed random effect would be the appropriate model. Otherwise, the random effect would be the appropriate model to adopt. The results show that the Hausman statistic is small. In other words, the p-value is large. Therefore, we fail to reject the null hypothesis which means the random effect is appropriate for this model. Hence, referring to the random effect test, it can be seen from the results of the pvalue after the robust test is 0.0054 which is $<0.05$. All of which means there is a 
significant impact of the independent variable capital adequacy ratio (CAR) on dependent variable Return on Assets (ROA).

\section{Discussion of the results Model 1: ROA}

Overall, comparing the capital adequacy ratio CAR of the data collected with CAR of Basel III, it is found that the selected Islamic banks in the selected MENA countries not only has a strong capital adequacy ratio. But it is also beyond that ratio Identified by Basel III. In details, the average CAR of the data selected is $19.27 \%$. This ratio is higher than Basel III ratio by $8.77 \%$. As a result, it can be said the selected Islamic banks can manage their potential financial risks efficiently. However, the highest CAR of the selected data during the period is $35.39 \%$ for the Safwa Islamic Bank in Jordan. This ratio might have a negative effect on the performance in which there is idle money unutilized to make profits for the bank during that quarter. In contrast, the lowest CAR of the selected data during the period is $8.10 \%$ for the al Baraka Islamic bank in Bahrain. This ratio also might have a negative impact on the banks' ability to manage their potential financial risks during that quarter especially it is lower than the CAR of Basel III 10.5\%.

Capital adequacy ratio (CAR) measures a bank's ability to finance and support risk-bearing assets. CAR is a measure of a bank's ability to cover equity losses could be incurred by risky assets. Hence, the bank's health is measured by the capital adequacy ratio (CAR) in which capital growth supports improving bank's income. Since large capital allows bank management to be more versatile in allocating funds to profitable investment opportunities. As a result, the higher the CAR, the higher the ROA. The Basel III Regulation implementing Capital Adequacy Ratio (CAR) states that the minimum CAR must be met by a $10.5 \%$ bank. Therefore, banks need always maintain the CAR ratio over $10.5 \%$. Nonetheless, a high CAR indicates that there is an idle fund which mean that bank's ability to raise profits will drop significantly, and the bank's profitability will suffer. The high CAR may be caused by the owner providing capital in the form of new money in order to predict the growth of the market size in the form of credit expansion. As a result of the large amount of idle funds, bank profitability as measured by Return On Assets (ROA) will continue to decline.

Data analysis revealed the existence of a significant and negative relationship between capital adequacy ratio and ROA in which the correlation coefficient was (0.0419364). The reason behind this result is the low return on assets at the studied sample during the study period. Furthermore, the return on assets for some banks like al Baraka Islamic Bank in Bahrain and Al-Izz Islamic Bank in Oman for some quarters was negative which ultimately caused this result. To explain, when ROA increases $1 \%$, it will cause the need for more capital for losses absorption goes down by $-0.0419364 \%$. The results of the study are also consistent with the study of (Alajmi \& Alqasem, 2015) who found that ROA is negatively influenced by CAR. In addition, the findings of this study is consistent with the studies were conducted by (Hawaldar et al., 2017), (Nahal, 2015) and (Tabash \& Hassan, 2017) who found that the CAR has an influence on the performance indicators including ROA. Further, this research is consistent with the study of (Polat \& Al-khalaf, 2014), (Alajmi \& Alqasem, 2015) as well as (Youssef, 2016) that found there is a relationship between CAR and ROA but that relationship is positive. In contrast, the finding of the study is inconsistent with (Bilal \& Salim, 2016) and (Hafez \& El-Ansary, 2015) who concluded that CAR has an insignificant effect on the performance ratios including ROA. While this study found the influence is significant. 
Results of Model 2: ROE

Summary of results of Model 2: $R O E$

Table 5. Results of Panel Data Analysis Dependent Variable: ROE

\begin{tabular}{|l|c|c|c|c|}
\hline \multicolumn{1}{|c|}{ Analysis } & Pooled OLS & $\begin{array}{c}\text { Random } \\
\text { Effect }\end{array}$ & Fixed Effect & $\begin{array}{c}\text { With } \\
\text { Robust }\end{array}$ \\
\hline Constant & 0.1564995 & 0.1272991 & 0.1248217 & 0.1564995 \\
\hline InVCAR & -0.3995142 & -0.2479977 & -0.2351433 & -0.3995142 \\
\hline Breusch-Pagan LM & \multicolumn{2}{|c|}{ Prob $>$ Chibar2= 0.0000} & - & 0.0000 \\
\hline Hausman test & \multicolumn{2}{|c|}{ Prob>Chi2= 0.5957} & 0.5957 \\
\hline Observations & 216 & 216 & 216 & 216 \\
\hline Serial Correlations & - & 0.0000 & - & 0.0000 \\
\hline Heteroskedasticity & - & 0.0000 & - & 0.0000 \\
\hline
\end{tabular}

Source: (Prepared by the author, 2021)

Through the previous Table 5.3, we can obtain the equation of the model ROE as the following:

$$
\mathrm{ROE}=0.1564995-0.3995142 \mathrm{CAR}
$$

\section{Analysis of the Model (2) ROE:}

The p-value of the Breusch-Pagan LM test is $<0.05$, according to the results. Consequently, there is panel data, indicating that the null hypothesis is rejected and that the random effect model is preferable to the OLS (pooled model).

\section{Random vs Fixed Effects}

Hypothesis:

$\mathrm{H}_{0}: \operatorname{Cov}\left(\alpha_{\mathrm{I}}, \mathrm{x}_{\mathrm{it}}\right)=0$ (Random Effect)

$\mathrm{H}_{1}: \operatorname{Cov}\left(\alpha_{\mathrm{I}}, \mathrm{x}_{\mathrm{it}}\right) \neq 0$ (Fixed Effect)

When the null hypothesis (H0) is rejected, the fixed effect model is used. The random effect model will be more applicable in this case. The Hausman statistic is low, which indicates the p-value is big, just as it is for the dependent variable $1 \mathrm{ROA}$. As a result, the null hypothesis is not rejected, indicating that the random effect is suitable for this model. As a consequence, the p-value for the random effect test is 0.000 , which is less than 0.05 , as determined by the robust result. As a result, the independent variable capital adequacy ratio (CAR) has a considerable influence on the dependent variable return on equity (ROE). 
As mentioned above in the discussion of the first model (ROA), CAR measures a bank's ability to finance and support risk-bearing assets. CAR is a measure of a bank's ability to cover equity losses that could be incurred by risky assets. Moreover, a bank with a large amount of capital can carry out its operational activities and can also bear the risk in the case of the bank is liquidated. Thus, the bank's health is measured by the capital adequacy ratio (CAR) in which capital growth supports improving bank's income. As a result, large capital allows bank's management to be more versatile in allocating funds to profitable investment opportunities. Data analysis revealed that there is a negative and significant relationship between capital adequacy ratio and ROE in which the correlation coefficient was (-0.3995142). This result can be attributed to the low return on assets at the studied sample over the study period.

Furthermore, the return on equity for some banks such Al-Izz Islamic Bank in Oman as well as al Baraka Islamic Bank in Bahrain for some quarters was negative which ultimately caused this result. To explain this coefficient, when ROE increases $1 \%$, it will cause the need for more capital to absorb losses decreases by -0.3995142 . This study is in agreement with the studies of (Tamimi \& Obeidat, 2013), and (Youssef, 2016) who found that there is a negative relationship between CAR and ROE. In addition, the findings of this study are in agreement with the studies conducted by, first, (Hawaldar et al., 2017), (Nahal, 2015) and (Tabash \& Hassan, 2017). Their studies found that the CAR has an influence on the performance indicators including ROE. In contrast, the finding of this study is inconsistent with (Bilal \& Salim, 2016) who concluded that Basel III implementation including CAR has an insignificant effect on the performance indicators including ROE. Similarly, the findings of this study are contrary to (Hafez \& El-Ansary, 2015) and (Alajmi \& Alqasem, 2015) study which found that there is no impact of CAR on the performance indicators excluding ROA.

\section{Conclusion}

It is of great interest to the financial community to implement the latest capital requirement regulations, also known as regulatory or capital appropriations, to reduce any risk from either the local or international. Financial institutions' performance is critical for good capital sufficiency and the ability to withstand the impact of any possible financial crisis. The aim of this study was to see how the Capital Adequacy Ratio (CAR) affected the performance of commercial Islamic banks in selected MENA countries between Q1 2017 and Q4 2019, as measured by both Return on Assets (ROA) and Return on Equity (ROE). The selected sample size is just (18) commercial Islamic banks. The data are collected from the disclosure of information and reports of these Islamic banks. The author utilized Panel data (Fixed and Random Effect Models) to analyze the data. However, The results of the study showed that the selected Islamic banks are committed to Capital Adequacy Ratio (CAR) which is defined under Basel III. The study found that there is statistically negative significant influence of CAR on both indicators of the performance ROE and ROA in the commercial Islamic banks in the selected MENA countries. The author advises future researchers to use other financial performance indicators and other variables from Basel III to study other effects of Basel III on the Islamic Banks. 


\section{References}

Abugamea, G. (2018). Determinants of Banking Sector Profitability: Empirical Evidence from Palestine. Economic Policy, 2116, 0-33.

Alajmi, M., \& Alqasem, K. (2015). Determinants of capital adequacy ratio in Kuwaiti banks. Journal of Governance and Regulation, 4(4), 315-322. https://doi.org/10.22495/jgr_v4_i4_c2_p3

AlAli, S. M. (2019). Influence of capital adequacy on financial stability indexes a field study in commercial banks in Jordan. Academy of Accounting and Financial Studies Journal, 23(4), 1-10.

Al-Hares, O. M., \& Saleem, K. (2017). Islamic Banks Financial Performance and Implications of Basel III Standards in the GCC: An Empirical Analysis. Review of Economics \& Finance, 7(February), 80-97.

Al-Hunnayan, S. H. (2020). The capital structure decisions of Islamic banks in the GCC. Journal of Islamic Accounting and Business Research, 11(3), 745-764. https://doi.org/10.1108/JIABR-02-2017-0026

Almanaseer, S. R. (2019). Determinants of Capital Structure: Evidence from Jordan. Accounting and Finance Research, 8(4), 186. https://doi.org/10.5430/afr.v8n4p186

Almazari, A. A. (2017). The effect of capital adequacy on profitability: a comparative study between samba and saab banks of saudi arabia, V(11), 86-102.

Bilal, Z. O., \& Salim, B. F. (2016). Does basil III implementation impact on financial performance? Evidence from Omani's commercial banks. International Journal of Economics and Financial Issues, 6(3), 963-970.

Butkova, O. (2020). The definition of capital as an economic and accounting category. E3S Web of Conferences, 175. https://doi.org/10.1051/e3sconf/202017513011

Chachi, A. (2006). Munawar Iqbal and Philip Molyneux Thirty Years oflslomic Banking: History, Performance and Prospects. Journal of King Abdulaziz University-Islamic Economics, 19(1), 39-41. https://doi.org/10.4197/islec.19-1.3

Deya'a. (2018). The Impact of Deposits and Credit Facilities on the Financial Performance of Banks in Palestine Stock Exchange.

Fatma, R. (2019). و اقع و أفاق تطبيق البنوك الاسلامية لمقررات بازل 3-مصرف الراجحي الاسلامي نموذجا. February.

George, D., Mallery, P., George, D., \& Mallery, P. (2020). Simple Linear Regression. IBM SPSS Statistics 26 Step by Step, April 2014, 193-207. https://doi.org/10.4324/9780429056765-16

Hafez, H. M., \& El-Ansary, O. A. (2015). Determinants of capital adequacy ratio: An empirical study on Egyptian banks. Corporate Ownership and Control, 13(1CONT10), 1166-1176. https://doi.org/10.22495/cocv13i1c10p4

Hawaldar, I. T., Kumar, K. A., Pinto, P., \& Sison, S. M. (2017). Performance Analysis of Commercial Banks in the Kingdom of Bahrain (2001-2015). International Journal of Economics and Financial Issues, 7(3), 729-737.

Hoffmann, P. S. (2011). Determinants of the Profitability of the US Banking Industry*. 2(22), 255-269.

Islam, Rashidul, S. E. E. (2015). How Earning Per Share (EPS) Affects on Share Price and Firm Value How Earning Per Share (EPS) Affects on Share Price and Firm Value. January 2014. 
Kabajeh, M. A. M., Al Nu'aimat, S. M. A., \& Dahmash, F. N. (2012). The relationship between the ROA, ROE and ROI ratios with Jordanian insurance public companies market share prices. International Journal of Humanities and Social Science, 2(11), 115-120.

Lenee, L., \& Sulaiman, A. (2016). Capital Adequacy Measures and Bank Financial Performance in Nigeria: A Cointegration Analysis. 3(1), 15-34.

Li, Y., Chen, Y. K., Chien, F. S., Lee, W. C., \& Hsu, Y. C. (2016). Study of optimal capital adequacy ratios. Journal of Productivity Analysis, 45(3), 261-274. https://doi.org/10.1007/s11123-016-0469-z

Molyneux, G. \&. (2006). Introduction to banking.

Nahal, J. (2015). Determinants of Bank Profitability Empirical Evidence from Syria.

Naz, F., Ijaz, F., \& Naqvi, F. (2016). Financial Performance of Firms: Evidence From Pakistan Cement Industry. Journal of Teaching and Education, 05(August), 81-94.

Polat, A., \& Al-khalaf, H. (2014). What Determines Capital Adequacy in the Banking System of Kingdom of Saudi Arabia ? A Panel Data Analysis on Tadawul Banks. Journal of Applied Finance \& Banking, 4(5), 27-43.

Riba, A. (2020). Tafseer.

Shahar, W. S. S., Shahar, W. S. S., Mohd Puad, N., Jamlus Rafdi, N., Ahmad Sanusi, S. W. S., \& Wan Hassin, W. S. (2017). The Historical Development of Islamic Banking. The 4th International Conference on Management and Muamalah, 2017(ICoMM), 503-508.

Tabash, M. I., \& Hassan, H. I. (2017). Liquidity, profitability and solvency of UAE Banks: A comparative study of commercial and Islamic Banks. Academy of Accounting and Financial Studies Journal, 21(2), 1-15.

Tamimi, D. K. A. M. A.-, \& Obeidat, S. F. (2013). Determinants of capital adequacy in commercial banks of Jordan an empirical study. Dirassat Journal Economic Issue, 4(2), 267-280. https://doi.org/10.6007/IJAREMS/v2-i4/53

Trivedi, R. (2013). Munich Personal RePEc Archive Evolution of the Concept of Capital - A Historical Perspective. 14208.

Yellapu, Vikas, 2018. (2010). Full Text Introduction. Text, 3, 2010-2012. https://doi.org/10.4103/IJAM.IJAM

Youssef, H. (2016). Determinants of Egyptian Banking Sector Profitability: Time-Series Analysis from 2004-2014 Heba. International Journal of Business and Economic Sciences Applied Research, 9(2), 73-7. 